\title{
IAN ALEXANDER McLAREN (1931-2020) - A LIFE IN BIOLOGY
}

\author{
ANDREW McLAREN ${ }^{1}$, JAMIE McLAREN ${ }^{2}$, \\ MARY McLAREN ${ }^{3}$ AND ERIC MILLS ${ }^{4 *}$ \\ ${ }^{1} 1447$ Brenton Street, Halifax, NS B3J 2 K6 \\ ${ }^{2}$ Institute for Chemistry and Biology of the Marine Environment, \\ Carl von Ossietzky Strasse 9-11, 26129 Oldenburg, Germany \\ ${ }^{3}$ Halifax, NS \\ ${ }^{4}$ Dalhousie University and University of King's College, \\ Halifax, NS
}

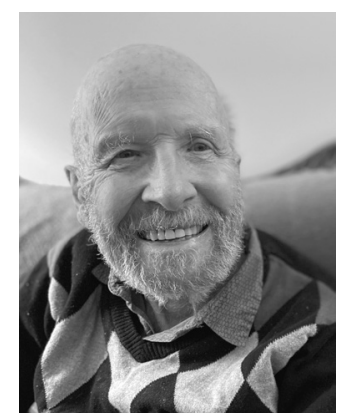

Fig 1 Ian Alexander McLaren (1931-2020), in Halifax in February, 2020 (Photo: Mary McLaren).

Marine biologist, Professor Emeritus, renowned birder, and longtime member of the Nova Scotian Institute of Science, Ian McLaren (Fig 1) is probably best known to most of us in Nova Scotia for his work on Sable Island, where for many years he made a small and rather inconspicuous bird, the Ipswich Sparrow (a localized subspecies of the widespread Savannah Sparrow), his special object of study. But there is a great deal more to be said about his highly varied and very productive life in science and society at large.

To summarize his career first. Born a naturalist, Ian McLaren spent a dozen summers researching Arctic animals before moving to Halifax to join Dalhousie University's Department of Biology in 1966. His numerous graduate students during four decades arrived from the world over, many working on the wildlife of Sable Island,

* Author to whom correspondence should be addressed: e.mills@dal.ca 
on marine mammals, and on zooplankton biology. At the same time, he kept up a very active life as an expert field ornithologist. He was the first President of the Canadian Nature Federation (now Nature Canada), editor of the Nova Scotia Bird Society's quarterly publication Nova Scotia Birds for many years, and was instrumental in establishing the Sable Island Preservation Trust and Nova Scotia Nature Trust. He will also be remembered by many Nova Scotians for his regular appearances through the 1990s and early 2000s on CBC Radio answering listeners' bird identification questions. His was a life of astonishing variety and remarkable accomplishments. A lifelong advocate for birding, field ornithology, conservation, and biodiversity, with noteworthy research contributions also in marine biology and ecology, Ian was unfailingly generous with his time for people in all walks of life, and widely admired for his affability and good humour.

Ian McLaren was born on January 11, 1931 to Alexander Lithgow McLaren, a painter and commercial artist, and Christine (née Tabrett) McLaren, a schoolteacher, in Montréal. His love of wildlife and adventure began in his pre-teen years, with entire days spent exploring and birding in the then plentiful woods in and near Montréal. One summer during his high school years, he shipped out for a summer as a deckhand on an ore carrier between Montréal, Dingwall, Nova Scotia, and South America. Apparently the stay in Dingwall made a big impression. He told us that, while there, the crew went ashore and found a dance in progress, which he joined. But it was mainly adults, and he and a similar-aged young woman soon tired of it, and at her suggestion they joined a kitchen-party in one of her relative's houses. Ian was surprised to find a language being spoken that he had never heard before - it was Gaelic, which even his Lowland Scots ancestors might not have understood.

Leaving the sea, at least temporarily, for academia, his studies at McGill University opened up the opportunity to spend summers in Eastern Arctic marine research under the supervision of Professor Max Dunbar, while he completed BSc and MSc degrees between 1952 and 1956.

Ian was an extensive Arctic traveler up to the mid-1960s, at first frequently aboard a storied research vessel, the Fisheries Research Board of Canada's small ketch Calanus (Fig 2). He told us that an important question Max Dunbar asked him before his first Calanus 


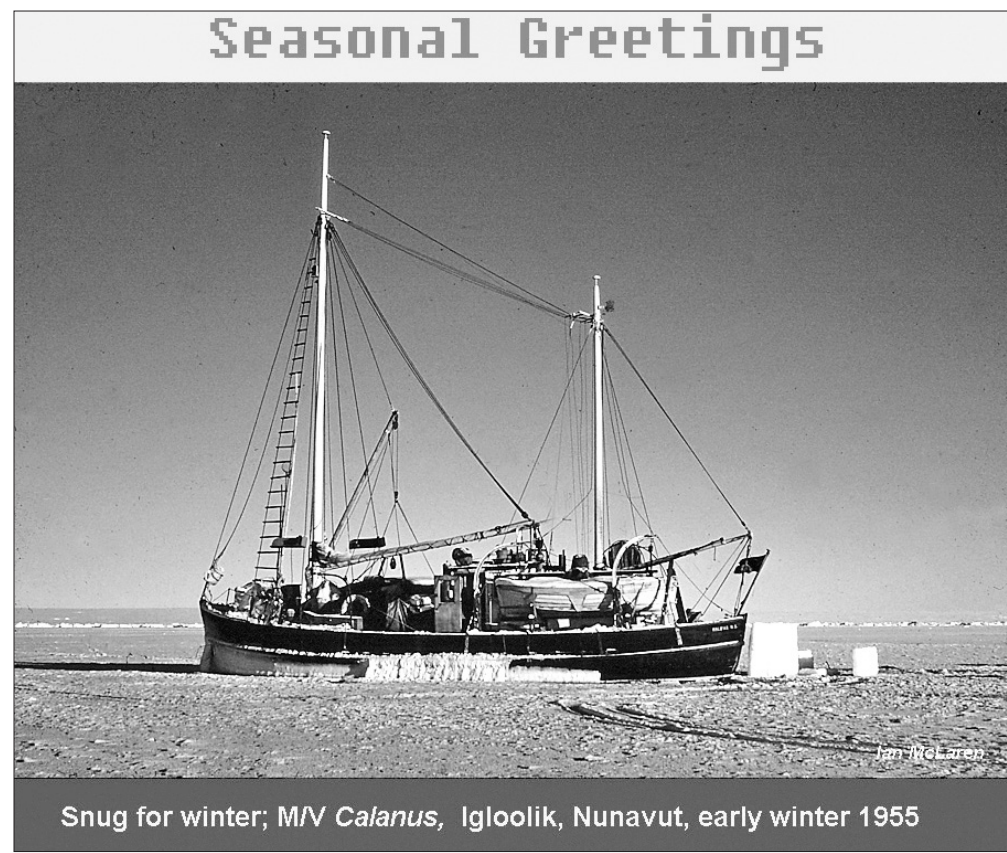

Fig 2 The M.V. Calanus of the Fisheries Research Board of Canada in 1955, off Igloolik, Nunavut, in one of Ian McLaren's Christmas greetings (Photo: Ian McLaren).

trip was how tall he was - because berths on the ship were very short. Even at that, as he told one of us, he sometimes slept on top of the engine, which he found more comfortable than a berth (presumably while the ship was not under power). Clearly, one way or another, he qualified for life on Calanus, spending three summers on the ship in the Eastern Arctic, 1951-1953. In 1954, in the course of his research on Ringed and Bearded Seals, he spent several months living with a group of Cape Dorset (Kinngait) seal hunters, carefully documenting his experiences in a vivid and memorable journal as well as carrying out his research. Ian especially enjoyed interacting with the Inuit people, whose rich lore and close-knit and vivacious culture left lasting impressions upon him. He met his wife Bernice (née Orchard) in Montréal between trips to the Arctic; they were married in her hometown of Miami, Manitoba, in October 1956. Bernice joined him as a research assistant (and diarist) when they spent the following summer of 1957 at Ogac Lake on Baffin Island (Qikiqtaaluk), studying its near landlocked Atlantic Cod and 
documenting the lake's plankton and other limnological features. During this period, 1955-1963, he was employed as a researcher with the Arctic Unit (later Arctic Laboratory) of the Fisheries Research Board in Montréal and Ste Anne de Bellevue. The McLarens moved to New Haven, CT, for a time, where, supervised by the noted ecologist G. Evelyn Hutchinson, Ian received a $\mathrm{PhD}$ at Yale University in 1961.

Ian taught at McGill University between 1963 and 1966. During this time, he brought to completion one of his most original works, on the adaptive value of vertical migration in zooplankton - in outline it suggested that zooplankton gained an advantage in growth by feeding in the warmer surface waters but metabolizing the food in cold deeper waters. This hypothesis stimulated a burst of activity on the phenomenon by many researchers. While at McGill, he found it convenient to do his field and laboratory work on zooplankton during summers at Dalhousie rather than in Montréal, and before long he was, in 1966, lured without difficulty to Halifax and Dalhousie University. He had recognized that Nova Scotia and Dalhousie had the potential to be a nexus of marine biology. Dalhousie in particular had a growing research faculty and proximity to many island ecosystems, in a far milder climate than the Arctic. It mattered, too, that the province was a birders' paradise and he soon took advantage of the opportunity to work on Sable Island (Fig 3), where he and his students studied bird biology, seal populations, and the resident horses.

At Dalhousie for 30 years, he led a full and at times frenetic life, publishing more than 100 peer-reviewed scientific articles and book chapters on marine mammals, zooplankton, ornithology, population biology, and ecological genetics, even well into his official retirement as George S. Campbell Professor of Biology Emeritus in 1996. He also served on the International Whaling Commission in 1982, leading to the first moratorium on whaling adopted by most nations that year, and on the Royal Commission on Seals and the Sealing Industry in Canada during the 1980s, as well as several other federal and provincial government panels.

Despite his many public and scientific advisory activities, Ian typically shied away from administrative positions, preferring to devote his efforts to graduate students and field research, while also teaching biology to thousands of undergraduate students, voluntarily 


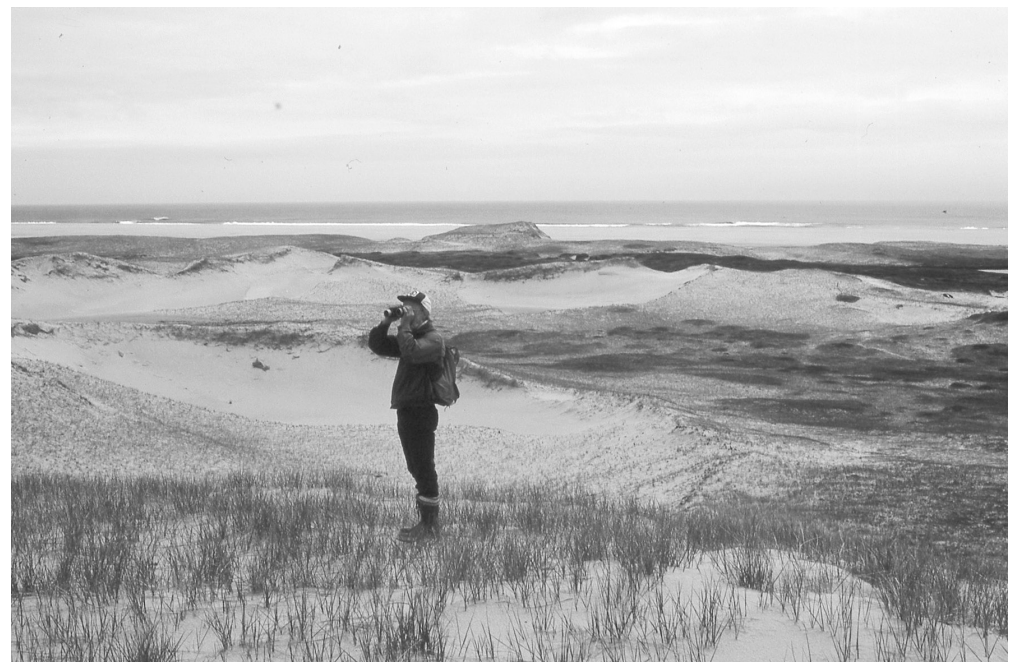

Fig 3 Ian McLaren in his preferred habitat, censusing Ipswich Sparrows in the Sable Island dunes, June, 1980 (Photo: Eric Mills).

taking on heavy teaching loads and serving on innumerable departmental and graduate-student committees. His educational and scientific impact was marked by his appointment to the George S. Campbell Professorship in Biology in 1984, and by several prestigious awards, including the Queen Elizabeth II Silver Jubilee and Diamond Jubilee medals, the American Birding Association's Ludlow Griscom Award for Outstanding Contributions in Regional Ornithology, and, most recently, Nature Canada's Douglas H. Pimlott Award for lifetime achievements in conservation. Through a generous private donation originating in his help to a student in distress, the Department of Biology at Dalhousie University established a graduate bursary in Ian's name in 2018.

Evaluating such a varied career and productive life, as family and colleague, is a challenging task. But considering his contributions as a biologist first, Ian McLaren was a world authority on seals, marine ecology, plankton and birds. His work, with several students and collaborators, on the biology and population ecology of marine copepods was world-class. His work, again always involving students, on Ipswich Sparrows on Sable Island, marked by major publications in the Proceedings of the Nova Scotian Institute of Science, moved an obscure and little-known sparrow to the forefront of population ecology and ornithology. He made the largest modern contribution 
since the great Robie Tufts to the ornithology of Nova Scotia, as shown in his editing and enlargement of the third edition of Tufts' Birds of Nova Scotia, the publication of the definitive All the Birds of Nova Scotia by Gaspereau Press, and many other writings on birds. As an environmentalist, by involving himself in the Canadian Nature Federation, the Sable Island Preservation Trust, and nearly every major environmental issue in the province during the past 50 years, he made an enormous contribution to the protection of Nova Scotia's natural environment. To us, he was a peerless parent, an academic's academic, a birder's birder, and a friend's friend. He is irreplaceable.

\section{SELECTED BIBLIOGRAPHY OF THE CONTRIBUTIONS OF IAN MCLAREN}

\section{(references in chronological order)}

McLaren, I.A. (1958). The biology of the Ringed Seal (Phoca hispida) in the eastern Canadian arctic. Bulletin of the Fisheries Research Board of Canada 118, $97 \mathrm{pp}$.

McLaren, I.A. (1960). Are the Pinnipedia biphyletic? Systematic Zoology 9: 19-28.

McLaren, I.A. (1963). Effects of temperature on growth of zooplankton and the adaptive value of vertical migration. Journal of the Fisheries Research Board of Canada 20: 685-727.

McLaren, I.A. (1967). Introduction to biological studies of Ogac Lake, a landlocked fiord on Baffin Island. Journal of the Fisheries Research Board of Canada 24: 975-980.

McLaren, I.A. (editor). (1971). Natural regulation of animal numbers. New York: Atherton Press. 195 pp.

McLaren, I.A. (1974). Demographic strategy of vertical migration by a marine copepod. American Naturalist 108: 91-102.

Stobo, W.T \& McLaren, I.A. (1975). The Ipswich Sparrow. Proceedings of the Nova Scotian Institute of Science 27, Supplement 2, 105 pp.

Corkett, C.J. \& McLaren, I.A. (1978). The biology of Pseudocalanus. Advances in Marine Biology 15: 1-231.

Boulva, J. \& McLaren, I.A. (1979). Biology of the Harbour Seal, Phoca vitulina, in eastern Canada. Bulletin of the Fisheries Research Board of Canada 200, 24 pp.

McLaren, I.A. (1981). The incidence of vagrant land birds on Nova Scotian islands. Auk 98: 243-257.

McLaren, I.A. (1981). The Birds of Sable Island, Nova Scotia. Proceedings of the Nova Scotian Institute of Science 31: 1-84. 
McLaren, I.A. (1985-1986). Survey of $19^{\text {th }}$ century ornithology in Nova Scotia, Parts I and II. Nova Scotia Birds 27 (2); 46-54; 27 (3): 65-71; and 28 (2): 71-79.

McLaren, I.A. (reviser, editor of Tufts, R.W. 1986). Birds of Nova Scotia. Third edition. Halifax, NS: Nimbus Publishing \& Nova Scotia Museum, $478 \mathrm{pp}$.

McLaren, I.A., Sévigny, J.-M. \& Frost, B.W. (1989). Evolutionary and ecological significance of variations in genome size among species of the copepod genus Pseudocalanus. Canadian Journal of Zoology 67: 565-569.

McLaren, I.A., Tremblay, M.J., Corkett, C.J. \& Roff, J.C. (1989). Copepod production on the Scotian Shelf based on life-history analyses and laboratory rearings. Canadian Journal of Fisheries and Aquatic Sciences 46: 560-583.

McLaren, I.A. (1993). Growth in pinnipeds. Biological Reviews 68: 1-79.

McLaren, I.A. (1995-1997). Nova Scotia rarities in perspective, Parts 1-4. Nova Scotia Birds 37 (2): 23-28; 37 (3): 25-30; 38 (2): 37-41; 39 (2); 27-32.

McLaren, I.A., Maybank, B., Keddy, K. \& Fitzerald, T. (2000). A notable autumn arrival of reverse migrants in southern Nova Scotia. North American Birds 54: 4-10.

McLaren, I.A. (chair of panel). (2001). Report of the Eminent Panel on Seal Management. Ottawa: Department of Fisheries and Oceans. 165 pp.

McLaren, I.A. \& Horn, A.G. (2006). The Ipswich Sparrow: past, present, and future. Birding 38 (5): 52-59.

McLaren, I.A., Lees, A.C., Field, C. \& Collins, K.J. (2006). Origins and characteristics of Nearctic land birds in Britain and Ireland in autumn: a statistical analysis. Ibis 148: 707-728.

McLaren, I.A. \& McLaren, J.D. (2009). An analysis of unusual flights of Neotropical migrants to northeastern North America in April 2009. North American Birds 63: 384-388.

McLaren, I.A. (2012). All the Birds of Nova Scotia. Status and Critical Identification. Kentville, NS: Gaspereau Press. 247 pp. 
